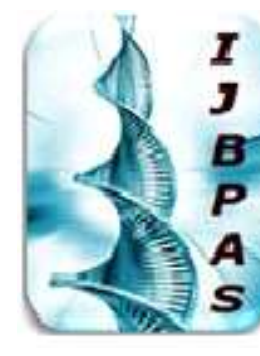

International Journal of Biology, Pharmacy

and Allied Seiences (IJBPAS)

'A Bridge Betusen Caboratory and Qqude'

WwW.ijbpas.com

PRAGMATIC ANALYSIS OF IAGO'S SELECTED SPEECHES IN SHAKESPEAREAN TRAGEDY 'OTHELLO'

\title{
HUSSAIN M
}

PhD Candidate, English Department, International Islamic University, Islamabad

*Corresponding Author: E Mail: hussain.phdeng101@iiu.edu.pk

Received $28^{\text {th }}$ Aug. 2019: Revised $20^{\text {th }}$ Sent. 2019: Accented $15^{\text {th }}$ Oct. 2019: Available online $1^{\text {st }}$ Feb. 2020

https://doi.org/10.31032/IJBPAS/2020/9.2.4940

\begin{abstract}
The present paper aims to analyze the extent to which the four maxims of cooperative principle are followed or violated/flouted by the central character Iago in Shakespearean tragedy "Othello" by employing Paul Grice's (1975) cooperative principle in order to come up with different interpretations of a single literacy text.. Furthermore, the reasons for selecting the character 'Iago' is to find out why the character 'Iago' has been placed as devil mind in the play by critics as it has been argued that "Evil has nowhere else been portrayed with such a mastery as in the character of Iago'(Bradley, 1951, p.206). Thus, the article investigates how the character uses language throughout the play in general and the four maxims in particular. Though, cooperative principle is helpful for a smooth and effective communication; however, people keep on violating the maxims in order to achieve certain purposes or to hide evil intentions which are in their minds. The findings show that the three maxims i.e. maxims of quantity, quality and relation have been violated by Iago in the play intentionally in order to hide his evil intentions and the character has used language as shelter.
\end{abstract}

Keywords: Pragmatics, cooperative Principle, conversational Maxims, Shakespearean Drama

\section{INTRODUCTION}

The present research article aims to explore Iago's selected speeches in one of the
Shakespearean tragedy 'Othello' in the light of Grice's Maxims. Language is a source of 
communication to others in different ways, such as spoken, written and by the use of gestures. It consists of words and symbols through which one can communicate to others, but it has been observed that language is manipulated and used as shelter even in colonial literature. Paul Grice (1975) argues that a successful communication is only possible when speakers and listeners follow certain strategies proposed in cooperative principle.

The maxims presented in the cooperative principle hold an important role in the conventional arrangement of conversation as according to $\mathrm{CP}$, a conversation or speech should be accurate, flawless, explanatory, and appropriate. Implicatures are generated through the maxims; however, the maxims are violated either intentionally or unintentionally in order to deceive the listener which is a violation of cooperative principles. Additionally, maxims are violated in order to give less or more answer; give false information without evidence; provide an irrelevant and ambiguous answer; similarly, Iago does in Othello.

According to Grice, One should follow certain strategies in order to have a smooth and effective conversation with others as Paul Grice (1975) proposed
Cooperative Principal which consists of four maxims: quality, quantity, relevance and manner which offers how people should follow certain rules in order to have a truthful, to the point, relevant and authentic conversation. Many linguists tend to apply the Cooperative Principles on the speaker's natural occurrences and conversation which, according to CP should be truthful, informative, and relevant and clear. Moreover, one can also analyze colonial literature by putting on the lenses of present day theories which are presented by postmodern and post-colonial literary scholars and come up with different interpretations of literary texts. The study may also provide new lenses to the students of English Literature to read colonial literature in new perspectives. Additionally, in the paper, Grice's four conversational maxims have been applied: 1) Maxim of Quantity; Quality; Relation and Manner.

The focus of the research paper is just limited to Iago's major five dialogues in act I of the play: Othello in order to know how Iago keeps on violating maxims and why he does it in the play, whereas the rest of the text and speeches are beyond the approach of this research paper. Moreover, for the sake of authenticity, two short Iago's speeches have also been taken to do a comparative 
analysis, whether Iago did not have command over language or Iago manipulated language and violated the maxims intentionally.

\section{REVIEW OF RELATED LITERATURE}

Paul Grice proposed four maxims of Cooperative Principle, which are very essential for communication. One can have an effective and smooth communication by following these maxims. Not only these maxims are violated in real life by people, however, these maxims are also violated in literary texts by characters in order to achieve certain purposes. Davies (2000) presented a research article in which she tried to differentiate between Grecians Cooperative Principle and literary cooperation drift.

A study was conducted on maxims of the cooperative principle by Nailufar (2001) in which she pointed out that the four maxims were flouted by all the characters intentionally as well as unintentionally in the drama "Death of a salesman" by Arther Miller. It was revealed in result that the characters violated the all four maxims of quality, quantity, manner and relevance. Along the same line a study was carried out by Bayram (2006) in which he tried to find out the difficulties faced by Turkish EFL students in writing English as well as Essays in Turkish language. The learners were selected from upper-intermediate level at the preparatory program of Istanbul Bilgi University. The researcher analyzed the essays by following Grice's maxims in order to point out how these maxims were violated in their essays by learners. It was revealed that the students who are unable to write relevant ideas and information in Turkish affects students writing skill in English as well. It was pointed out by applying maxims of relevance in their writing. Two conclusions have been drawn from the study, a) the maxim of relation could be super ordinate maxims, so the violation of the relation maxim in L2 can happen due to violation of other maxims in L1.

The violation of the maxim of manner in Turkish and the violation of Quantity maxim in English share the same reasons. Moreover, students were unable to provide more information in English essays, however, the maxim of manner was violated more because of excessive repetitions (Bayram, p 86, 87). In the same vein, Li Jia (2008) discussed the violation of Cooperative Principle and the four maxims in psychological consulting perspective in which she argued that violation of the maxims of cooperative principle is affected by specific psychological environment. Three excerpts from the novel "The Female 
Psychologist" by B.I. Shumin, were analyzed. Her result revealed that conversational implicature and the violation of cooperative principle are closely related. It was further pointed out that the violation happens owing to the special needs of psychological consulting. She concluded that the flouting of $\mathrm{CP}$ often happens in the context of psychological consulting, due to the needs in the specific context.

Hamid and Behija (2009) conducted a study on "Pragmatics: Grice Conventional Maxims violation in the response of some western politicians" in which researchers applied Grice four maxims to some political interviews in order to know that how much these four maxims were followed by the politicians, however, the maxim of quality was given more importance because it is the moral duty for politicians to be truthful to their public. It can be concluded that maxims of quality as well as quantity were more violated than the maxims of manner and relevance by politicians. An attempt was made to apply Grice's maxims on literary text by Khosravizadeh and Sadehvandi (2011) entitled "Some Instances of Violation and Flouting of the Maxim of Quantity by the Main Characters (Barry \& Tim) in Dinner for Schmucks." The results revealed that the character Barry in the play, Dinner for
Suchmucks, keeps on flouting the maxims of quantity more than the character. It was further pointed out that constant violation of the maxims of quantity by Barry placed the character in a higher position in terms of verbal humor.

Moreover, Kheirabadi and Aghagolzadeh (2012) penned down an article in which the application of Grice's maxims on news selection was determined. Furthermore, it was further proposed that newscasters have audience; therefore, maxims of cooperative principle can be applied to it. They also tried to present that how Gricean maxims can be applied on selection of news forecasting. A study was carried out in Pakistan by Bilal and Sumaira (2013) in which dialogue of the then president of Pakistan were probed by applying the maxims of the cooperative principle in which the researchers revealed in their results that elected persons are answerable to public. However, they try to make publicly contended by their colorful words and by diverting the attention of the public from the real issues of everyday life. It was further pointed out that the president flouted the four maxims in order to avoid answering the anchor in a Pakistani Talk show. 
In a study, Afsaneh \& Ahmed (2015) conducted a study "Grecians Maxims of Quantity: A comparative Study of articles Written by Iranian Authors and Native Speakers of English" in which they produced and compared texts of Iranian and native speakers of English with reference to Grice maxims of quantity. In the study 30 psychological articles written by Iranian and native speakers of English, were analyzed. The researchers concluded that the native speakers of Persian Language as well as the native speakers of English Language violated the maxim of quantity in their English writing. No study has been carried out in terms of the cooperative principle, on the dialogue of the most devil mind character 'Iago' in the world of English Literature. The frequent violations of maxims by Iago placed the character as one of tricky and evil characters in the play as well as in the world of literature. Therefore, the present study is conducted in order to find out how Iago used language as shelter, which has placed him as evil mind the eyes of readers and how he violates the maxims. It is an attempt to come up with different interpretations of a single literary text which may be helpful for the students of English literature. A bulk of studies (see, Ning ; Caixia, \& Yuan, 2018; Muhassin, 2019; Qiu, 2019; Xin \& Liang,
2019; Davies, Enokida, \& Fraser, 2017; Mandarani, 2017 among others) have been produced on cooperative principles.

\section{Analysis}

\section{(1) Roderigo:}

Thou told'st me thou didst hold him in thy hate

\section{IAGO:}

"Despise me, if I do not. Three great ones of the city

to

And I-God bless the mark! - his Moorship's ancient"1

In the above dialogue, Iago violates the maxims of quantity and relation because when Rederigo (lover of desdemone) asks him "Thou told'st me thou didst hold him in thy hate." Iago replies "Despise me, if I do not" is relevant; however, He keeps on saying and gives an irrelevant further lengthy answer of 194 words which is a clear evidence of Iago's redundant nature, Hence, according to cooperative principle as well as from researcher's point of view, the character violates the maxims of quantity because the answer 194 words, in the response of merely a single sentence, more than what is required. On the other hand, Iago also violates the maxims of relation because he gives an irrelevant answer. Thus, It has been observed that Iago violates/flouts the maxims of

${ }^{1}$ http://shakespeare.mit.edu/othello/full.html 
quantity as well as relation in the above mentioned dialogue.

The purpose behind violation of the maxims of quantity and relation is to hide his reality because he uses Rederigo as a tool and spends his wealth as it has been said by Rederigo "Tush! never tell me; I take it much unkindly That thou, Iago, who hast had my purse As if the strings were thine, shouldst know of this" in this dialogue Roderigo says as its string were thine means he handed over his wealth to Iago. Thus, he violates maxims of quantity and relation so that he may poison Roderigo's mind further. As a result, it can be said that Iago manipulated language in order to fulfill his evil intentions.

\section{(2) Roderigo:}

By heaven, I rather would have been his hangman.

\section{IAGO:}

Why, there's no remedy. 'Tis the curse of service,

to

to love the Moor. ${ }^{2}$

In above dialogue, in response to a single sentence, uttered by Rederigo "By heaven, $I$ rather would have been his hangman." Iago gives a superfluous answer which is not required at the stage. He, here too, violates the maxim of relation as his main purpose is to sow a seed of hatred in Roderigo's mind because Iago wants to use Roderigo for his personal interest in order to take revenge from Othello who gets marriage with Desdemona. Moreover, by calling Roderigo as "sir, (be judge yourself)", he wants to take Rederigo into his confidence. Apparently, Iago is in favor of Roderigo, but in reality he isn't. He violates the maxims of relation and quality because his response is not relevant as well as false to the response of initiation uttered by Roderigo. However, this speech is a bit shorter than the first dialogue because it contains forty five (45) words. Consequently, it is a more violation of relation and quality than quantity

\section{(3) Roderigo:}

I would not follow him then.

\section{IAGO:}

$\mathrm{O}$, sir, content you.

to

For daws to peck at: I am not what I $\mathrm{am}^{3}$

In response of Rederigo's single sentence "I would not follow him then". ,Iago delivers redundant speech which is a vivid example of violation of the maxims of quantity and relation. Iago's response:

"O sir, content you.

I follow him to serve my turn upon him"

Up to "my turn upon him" is relevant what Roderigo says in first initiation, however, the rest of the speech is a violation

${ }^{3}$ http://shakespeare.mit.edu/othello/full.html

${ }^{2}$ http://shakespeare.mit.edu/othello/full.html 
of quantity as well as maxims of relation. Because, his response (204 words), is redundant as well as irrelevant. According to the researcher's point of view, Iago violates both maxims intentionally because he wants to take Roderigo in his confidence, on the other hand, he knows that Roderigo is against Othello, this is why he speaks irrelevant and over informative dialogue and hides his evil intention as he keeps on talking and violating the maxims intentionally.

\section{(4) Roderigo:}

What a full fortune does the thicklips owe, If he can carry't thus!

IAGO:

Call up her father, to

As it may lose some color. ${ }^{4}$

In the above dialogue Iago responds to Rederigo's initiation

"What a full fortune the thick lips owe If he can carr't thus!"

The above response uttered by Iago, is a violation of the maxims of relation because Rodergo talks about Othello, with whom, Desdemona elopes, in response to the initiation, Iago gives an irrelevant response. $\mathrm{He}$ wants to provoke Roderigo against Othello and try to divert the attention of Roderigo towards Brabantio (father of Desdemona and senator in Venice) so that
Rederigo should make his mind to go with him in order to inform Brabantio about the elopement of Desdemona with Othello. In reality, Iago himself wants to inform Brabantio but he uses Roderigo for it. Hence, Iago breaks the maxims of relation intentionally, however, Iago does not violate/ flout the maxim of quantity in this conversation.

\section{(5) Roderigo:}

It cannot be.

IAGO:

It is merely a lust of the blood and a permission of

to

to be drowned and go without her. ${ }^{5}$

If we analyze the above dialogue closely, we come to know that Iago, not only breaks the maxims of quantity and relation but also he violates maxim of quality in the above speech when, in response of Roderigo's initiation "It cannot be" ,Iago tries to give a false information by saying " it is merely a lust of the blood and a permission of the will " and the second sentence when he says "it cannot be that Desdemona should long continue her love to the moor", The both sentences are the violation of the maxim of quality because he is telling lie and gives a false information to Roderigo that Othello and Desdemona will become fed up of each

\footnotetext{
${ }^{5}$ http://shakespeare.mit.edu/othello/full.html
} 
other soon and he (Iago) will help Roderigo in getting Desdemona for him. In reality, Iago wants to make Roderigo agree of giving him money and he wants to grab Roderigo wealth when he says "put money in thy purse; follow thou the wars; defeat, they favor with a usurped beard; I say, put money in thy purse". Not only the maxim of quality has been violated but also maxims of quantity and relation have also been violated by Iago in the above speech when he begins to give a superfluous and irrelevant answer of a just single sentence "It cannot be" uttered by Roderigo. Consequently, the researcher came to know that Iago violates the maxims of quality, quantity and relation in the speech.

\section{Two selected speeches for Comparative} Analysis

The following two dialogues have been selected to do comparative analysis in order to explore whether Iago does not have command over language or Iago violates the maxims intentionally in order to hide his evil intentions.

(1) Roderigo:

Where shall we meet i' the morning?

IAGO:

At my lodging. ${ }^{6}$

In above conversation, Iago follows the maxims of relation and quantity when
Roderigo asks him "Where shall we meet $i$ ' the morning? Iago's answers "At my lodging" is relevant and short, thus, it can be concluded that Iago follows all the maxims in the above speech; however, one can say that Iago has command over language; however, he violates the maxims of cooperative principle in the play intentionally, it is revealed that Iago knows how to speak relevant and to the point, however, he intentionally keeps on violating the maxims of quantity and relation.

\section{(2) Roderigo:}

I will incontinently drown myself.

IAGO:

If thou dost, I shall never love thee after.

Why, thou silly gentleman! ${ }^{7}$

In the above conversation, Iago tries to console Roderigo and asks him not to take the extreme step of drowning himself. It is again revealed in the analysis that Iago gives to the point response to Roderigo's initiation. Neither has he flouted the maxim of quantity nor relation in the speech. Because he already provoked Roderigo and brought him to the extreme, therefore, Iago is no longer violates maxims at this stage as he doesn't need to do it. It shows that Iago better knows how to answer to the point and relevant; however, he intentionally violates four

${ }^{7}$ http://shakespeare.mit.edu/othello/full.html

${ }^{6}$ http://shakespeare.mit.edu/othello/full.html 
maxims in order to fulfill his own purposes and evil interests.

\section{DISCUSSION AND CONCLUSION}

By following the question: to what extent and why does Iago violate the maxims of cooperative principles? The results of the study reveal that the maxims of quantity, relation and quality have been violated by Iago in Shakespearean play 'Othello' in order to hide his reality and evil intentions as Iago is such a complicated character in Othello (Shakespearean Tragedy) that nobody in the play understands him. Furthermore, he violates these maxims for different reasons, i.e., He hides his inner intentions; his real face in order to take his revenge against Othello as well as even his wife does not understand his inner intentions in the play. Thus, he breaks the conventional rules of cooperative principles. Consequently, it can be said that What Iago is, he is not; what he is not, he is, because he can be called as the mastermind of violating the maxims in the play and manipulating language. Iago violates the maxims intentionally throughout the play.

It has been generally observed that people also flout and violates the maxims of the cooperative principle in everyday life while communicating to others for different purposes. They keep on violating them because of telling lies; hiding his reality; hiding his inner evil intentions, diverting the attention of listener to something else instead of the main issues; people in authority exploit and manipulate language in order to rationalize themselves as a result they violate these maxims. Additionally, Most of time politicians violate these maxims in public in order to fulfill their own purposes. Language in general, Grice maxims in particular are flouted and violated to divert the attention of the masses from the real issues. However, it may also be said that sometimes people flout and violate the maxims by mistake. They may not have a grip over language while communicating to others. In a nutshell, the results show that the maxims of cooperative principle have been violated intentionally by Iago, even though, he has command over the language but he manipulates language in the play.

The following recommendations can be drawn from the findings that when we communicate to others, certain conventional maxims of cooperative principle should be followed while talking to the response to any question or initiation. When we speak, we should avoid ambiguity, we should not say what we believe to be false and we should avoid speaking about what we lack adequate evidence as well as our communication must 
be relevant to the topic or matter that is being communicated or discussed and should not be over or less informative.

\section{RECOMMENDATION FOR FURTHER RESEARCHERS}

a) This study is just limited to the five major and two minor Iago's speeches. One can do research on the rest of the Iago's speeches in the play.

b) After analyzing the selected speeches, the researcher found out the three maxims i.e. maxims of quantity, quality and relation have been violated by Iago. One can do further research on the rest of the speeches in order to point out maxims of manner as well.

c) One can also apply the cooperative principle on the speeches of politicians, talk shows, and other postmodern literary texts.

d) New researchers may also apply it on dialogues in movies and dramas

e) Literary texts can be taught by various modern methods, avoiding single traditional method. Teachers should teach students literary texts by various methods of interpretation of literary texts.

\section{REFERENCES}

[1] Bilal, H.A., \& Sumeria, N.(2013). Probing into the dialogue of the president of Pakistan: Application of Grice's maxims. Thesis, University Of Sargodha, Pakistan.

[2] Bradley, A. C. (1951). Shakespearean tragedy: Lectures on Hamlet, Othello, King Lear, Macbeth. London: Macmillan \& Company.

[3] Davies, B. (2000). Grice's cooperative principle: Getting the Meaning Across. In Nelson, D., Foulkes, P. (Eds.). Leeds Working Papers in Linguistics, 8, 1-26.

[4] Davies, W., Enokida, K., \& Fraser, S. (2017). Speech Acts, Social Reality, and the Cooperative Principle in Joseph Conrad's Lord Jim. Hiroshima Studies in Language and Learning, 20, 115-134.

[5] Foroughi A, A, \& Reza L, A. (2015). Grecians maxims of quantity: A comparative Study of Written by Iranian Authors and Native Speakers of English. Islamic Azad University, Isfahan: Research Journals of recent Sciences.

[6] Gee, J. P. (2010). An Introduction to Discourse Analysis: Theory and Method. Routledge. 
[7] Grice, H. P. (1975). Logic and conversation. In P. Cole, \& J. Morgan (Eds.), Studies in Syntax and Semantics III: Speech Acts (pp. 183198). New York: Academic Press.

[8] Hamadi, H., \& Muhammad, J.B (2009). Pragmatics: Grice conventional maxims violation in the response of some Western politicians. University of Basra-College of Arts.

[9] http://shakespeare.mit.edu/othello/ful. $\underline{\mathrm{html}}$

[10] Jia, L. (2008). The violation of cooperative principle and the four maxims in psychological consulting. Canadian Social Science, 4(3), 8795.

[11] Kheirabadi, R., \& Aghagolzadeh, F. (2012). Grice's cooperative maxims as Linguistic criteria for news selectivity. Theory and Practice in Language Studies, 2(3), 547553.http://dx.doi.org/10.4304/tpls.2. $\underline{3.547-553}$

[12] Mandarani, V. (2017). Cooperative Principle used by the Vendors of Borobudur Temple in Communication with Foreign Tourists. KnE Social Sciences, 1(3), 319-325.
[13] Muhassin, M. (2019). Students' violation of cooperative principle in thesis exams. LEKSIKA, 13(2), 6571.

[14] Nailufar, Y. (2001). Flouting maxims on Grice's maxim in the drama of 'the Death of a Salesman'. Sarjana Humaniora (S. Hum) Thesis, State Islamic University of Malang.

[15] Ning, Z., Caixia, W., \& Yuan, G. (2018). An Analysis of Humor in The Big Bang Theory Based on The Cooperative Principles. In 2018 International Conference on Arts, Linguistics, Literature, and Humanities (ICALLH 2018) (pp. 323-326).

[16] Parvaneh, K., \& Nikan, S. (2011). Some instances of violation and flouting of the maxim of quantity by the main characters (Barry \& Tim) in dinner for Schmucks. International Proceedings of Economics Development \& Research, 26, 122.

[17] Qiu, J. (2019). Pragmatic Analysis of Verbal Humor in Friends-Based on Cooperative Principle. Theory and Practice in Language Studies, 9(8), 935-940. 
[18] Shakespeare, W. (1903). The tragedy of Othello (Vol. 27). Methuen.

[19] Xin, L. I., \& LIANG, X. (2019). Analysis of the Humors in Yue Yunpeng's Cross Talks: Based on Cooperative Principles. CrossCultural Communication, 15(2), 2934.

[20] Zor, B. M. (2006). Using Grice's Cooperative Principle and its maxims to analyze problems of coherence in Turkish and English Essays (Master's thesis, The Graduate School of Social Sciences of Middle East Technical University, Ankara, Turkey. 